\title{
COPING WITH EGYPT'S AND ISRAEL NORMALISATION PROCESS: GAZA STRIP SIEGE AND HAMAS GOVERNANCE
}

\begin{abstract}
JOÃO PEDRO BORRALHO
joao pedro borralho@iscte-iul.pt

João Borralho is currently enrolled in the PhD programme in International Studies at ISCTE-IUL (Portugal) with a project focusing on hunger strikes led by Palestinian prisoners in administrative detention. He got a Bachelor's Degree in International Relations and a Master's Degree in International Studies from ISCTE-IUL. His main areas of interest are Middle Eastern Studies, grassroots movements and international relations theory.
\end{abstract}

\begin{abstract}
Over the last fourteen years, the Gaza Strip has been under a land, sea and air siege imposed by Israel and Egypt. Throughout these years, Palestinians from the Gaza Strip have endured three Israeli military operations inside a besieged territory and have seen their lives becoming increasingly hard to bear. Moreover, to contain 2 million people inside a $365 \mathrm{~km}^{2}$ enclave, Israel has received continuous support from Egypt. Hence, the article's focus is the EgyptianIsraeli relationship from 1981 to 2017, the Gaza Strip siege, the Hamas governance and how the asymmetric relations between Egypt and Israel with Gaza and its inhabitants materialise. Furthermore, due to events such as the peace treaties signed between Israel with United Arab Emirates, Bahrain, Morocco and Sudan, Israel's refusal to let Covid-19 vaccines entering the Gaza Strip and the election of Israel's new coalition government, the topics examined in this article are increasingly relevant.
\end{abstract}

\section{Keywords}

Gaza Strip Siege, Normalisation Policy, Israel Egypt, Foreign Policy

How to cite this article

Borralho, João Pedro (2021). Coping with Egypt's and Israel Normalisation Process: Gaza Strip Siege and Hamas Governance. Janus.net, e-journal of international relations. VOL12 N2, TD2 - Thematic dossier The Middle East. Local dynamics, regional actors, global challenges, February 2022. Consulted [online] in date of the last visit, https://doi.org/10.26619/16477251.DT0122.1

Article received on March 15, 2021 and accepted for publication on October 20, 2021

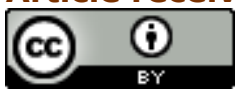




\title{
COPING WITH EGYPT'S AND ISRAEL NORMALISATION PROCESS: GAZA STRIP SIEGE AND HAMAS GOVERNANCE
}

\author{
JOÃO PEDRO BORRALHO
}

\section{Introduction}

The Egyptian-Israeli relation has been complex and very dynamic ever since Israel's State creation in 1948. On the one hand, Egypt fought four wars with Israel; on the other, it signed a Peace Treaty in 1979, breaking the Arab consensus of isolating Israel and eroding the Palestinian cause (Stein, 1997: 315). Hereafter, a growing policy of normalization between these two countries has been taking place where, currently, Egypt is supporting Israel's siege ${ }^{1}$ of the Gaza Strip. This is important since one of the article's primary goals is to understand the contemporary situation in the Gaza Strip, and this can only be done if the context that helped to produce the present-day Gaza is considered.

Therefore, the article will analyze the dynamics between Egypt, Israel and the Gaza Strip to understand how (i) the Egyptian-Israeli relationship has always helped or hindered conditions in this territory, (ii) how the siege has detrimental consequences for the territory, and (iii) how Hamas has been governing the enclave throughout the fourteen years of siege. This is relevant because the article addresses these topics as interconnected issues, which helps develop the existing research in the Portuguese academia and overcome the lack of understanding of the Hamas government and the Palestinians living in the Gaza Strip. As Sara Roy frames it, "(...) reality is always far more complex, differentiated, and irreducible than the stereotypes that are typically constructed for us" (2011: 17). Therefore, in this article, I tried to make understandable the power dynamics happening between these units, to demonstrate what is happening inside the Gaza Strip and how, as the title demonstrates, is the Hamas government coping with the ongoing siege.

To achieve this, it is essential to consider the following consequences from the start: $80 \%$ of the population is dependent on aid; $44 \%$ is unemployed; $40 \%$ is considered to be poor; $60 \%$ is food insecure; access to safe drinking water fell $98.3 \%$ from 2000 to $10.5 \%$ in $2014 ; 45 \%$ of essential medicines are not available; and, in average, there are only 2 hours per day of electricity (UN Report, 2017: 20; B'Tselem, 2017: 1). Moreover, doubling down on this dire situation, Palestinians cannot leave the Gaza Strip (due to the

1 According to Ron J. Smith, a siege is a "(...) measure which is put in place from the state level upon populations who see their basic needs, liberties and freedom denied with the aim of leading to political change" and that in the case of Palestine is also a "subset of occupation practices" (2016: 750). 


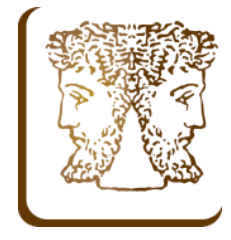

siege), rendering them powerless to travel or look for a better future overseas. These numbers and the awareness that Israel, were it not for Egypt's help, could not cause such a humanitarian disaster inside the Gaza Strip leads to the question: "How has Egypt foreign policy towards Gaza evolved from 2006 to 2017?" (Borralho, 2020: 2). This, together with an analysis of Egyptian-Israeli relations, will be answered in the following sections of the article.

\section{Mubarak's Rule: Following President Sadat's Legacy and Beyond}

Hosni Mubarak came to power after the assassination of President Sadat in 1981, and if he was not the one who signed the 1979 Peace Treaty with Israel, he was the one who executed it and made it a pillar of Egypt's foreign policy in the region. What would this mean to the Palestinians and their national movement? What changed in Egypt's foreign policy towards Israel and Palestine?

Three levels of analysis must be considered (Borralho, 2020; Abadi, 2006). First, the Egyptian government's foreign policy (political, diplomatic, economic and security dimensions). Second, Egyptian civil society, meaning that it is critical to understand whether Egyptian society has had the agency to constrain the governments' foreign policy or not. Third and last are the external constraints (neighbouring Arab countries). Besides these three levels, it is important to bear in mind that during Mubarak's rule, he had three major goals that also impacted his ability to make decisions: the improvement of Egypt's economy; recovering Egypt's status as the leading nation of the Arab world; and the conservation of USA support for his regime (which would only happen through the conservation of the peace treaty with Israel) (Kenneth Stein, 1997: 319; Ewan Stein, 2011: 739). With this in mind, Mubarak's foreign policy has been divided into three stages: 1981 to 1993, 1993 to 2006 and 2006 to 2011 (Borralho, 2020: 18). Throughout these three stages, Egypt's relationship with Israel progressed from 'cold peace' to 'strategic peace' (Aran and Ginat, 2014)².

\subsection{Three-stage Relationship with Israel}

In the first stage (1981 to 1993), Mubarak's regime faced several constraints imposed by Israel that caused and maintained the cold peace. For instance, Israel's 1981 bombing of Iraq's nuclear facilities; the invasion of Lebanon in 1982 and the Sabra and Shatila massacre of Palestinians; Israel's annexation of East Jerusalem; settlements expansion in the occupied Palestinian territories (oPt); the backlash against Palestinians during the First Intifada (Stein, 1997: 306). These events, among others, hindered the relationship on the state-level, alienated Egyptian civil society's support of relations with Israel and increased the support for the Palestinian cause. Moreover, Mubarak's goal of regaining the confidence of the Arab neighbours (that had expelled Egypt from the Arab League in 1979) led him to take measures to reduce to a minimum the social and economic integration of both countries (Borralho, 2020: 20). In sum, the first stage was where

2 Strategic peace is an intermediary stage between cold peace and stable peace. Therefore, it should be understood in a continuum wherein one side is cold peace and the other stable peace. 


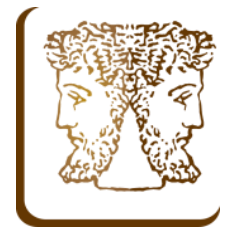

Mubarak most felt compelled by the domestic and external constraints and where he most vividly linked the Palestinian progress (or lack of it) to the normalization of ties with Israel. For these reasons, and although the peace treaty was working because neither would resort to war, their relations were cold.

The second stage (1993 to 2006) should still be understood within the cold peace perspective for reasons such as the backlash against Palestinians during the Al-Aqsa Intifada, the electoral victory of the Likud Party, Israeli Operation Deterrent Shield in the oPt, and finally, due to Egypt's civil society pressure (Stein, 1997: 313; Stein, 2011: 751; Khani, 2013: 102). Nevertheless, Egyptian-Israeli relations still improved on the state-level for three main reasons. The first was the USA's policy change towards Mubarak's regime from conflict reduction to mutual strategic interests. Consequently, Egyptian-Israeli relations not only improved (as a consequence of their common links to the USA), but Egypt became a peace mediator of the political dialogue between Palestinians and the Israelis (Aran and Ginat, 2014: 566). The second reason, which came to consolidate the first, was the Oslo Accords. Mubarak instrumentalized them in his favour and pursued his mediator role between Israel and the PLO and other Arab countries (Abou-El-Fadl, 2012: 10). With this, he successfully legitimized the growing relations on the state-level and made Egypt the "(...) central axis for influencing Arab attitudes and the pace of Arab normalization with Israel" (Stein, 1997: 313). Lastly, Iran also played a role in Egyptian-Israeli relations because both countries saw Iran as an enemy to the status-quo that the peace treaty and USA foreign policy had positively brought them (Aran and Ginat, 2014: 15). Therefore, and although still self-conscious of Egypt's civil society agency's constraints, Mubarak's foreign policy gradually changed during this stage.

On the third and last stage, the former cold peace evolved into strategic peace. Two events must be acknowledged as the most important regarding Mubarak's foreign policy towards the Gaza Strip and its inhabitants. The first was Hamas' electoral victory in the 2006 Palestinians Elections and consequent siege, and the second was his compliance with Israel during Operation Cast Lead (OCL) in 2009.

To understand Mubarak's stance on Hamas, it is important to know that he was losing popularity inside Egypt to the Muslim Brotherhood (MB) ${ }^{3}$. Mubarak depicted the MB as an illegal organization that exploited religion and the fragility of citizens to accomplish their goals (Meital, 2010: 179). He did the same towards Hamas with the aggravating that he saw them as a proxy of Iran. For this reason, when Hamas won the Palestinian elections and took over the Gaza Strip, Egypt followed Israel's decision to commence a siege into this territory with complete disregard of the consequences for the Palestinian citizens by closing the Rafah crossing ${ }^{4}$.

What is more, intending to lead to political change, Egypt and Israel's security and intelligence sharing coordination reached hitherto unknown levels (Borralho, 2020: 24).

3 The relationship between Hamas and the MB originates from the fact that the first is a product of the Political Bureau of the latter that existed in Gaza since 1946. During the first Intifada, Palestinian MB changed from their non-violent approach to actively support and participate in confrontation with the Israeli occupier, which led to the creation of the Islamic Resistance Movement, whose acronym in Arabic is Hamas (Hroub, 2002).

4 Egypt's border with the Gaza Strip. 
This siege sealed the Gaza Strip from the rest of the world, aggravating an already dire economic situation and increasing the humanitarian distress of Palestinians. To circumvent this situation, Hamas started to build illegal tunnels on the border with Egypt that helped them to evade, for a while, the worst effects of the siege. This changed when Israel initiated the OCL (2008-2009) following a violation of their ceasefire with Hamas. After twenty-six days of Israel's offensive inside the Gaza Strip that killed 1,400 Palestinians and injured more than 5,000 (on the Israeli side, nine soldiers were killed and 113 wounded) (PCHR, 2009: 6; Amnesty International, 2009: 6; B'Tselem, 2009: $3)$, Mubarak's decisions during and after Israel's military operations, increased the hardships inside the enclave ${ }^{5}$.

Along with his domestic policies, Mubarak's foreign policy started to stir Egyptian civil society like never before. Mubarak had indeed achieved strategic peace with Israel but forgot how critical the need to balance the domestic constraints was (Borralho, 2020: 28). Egyptian civil society took the few public demonstrations authorized in favour of Palestine to their advantage to initiate their struggle against Mubarak's regime. The Egyptian Arab Spring had begun, and "(...) Palestine's activism became an incubator for the protest movements that led (...) to the Egyptian uprising" and Mubarak's fall (AbouEl-Fadl, 2012: 12).

\section{President Morsi one-year in Power}

Hailing from the Freedom and Justice Party ${ }^{6}$, President Morsi was democratically elected eighteen months after Mubarak's ouster. The first presidential election of someone from an Islamist party raised several questions. To the scope of this article, three are critical: what would this election mean to the Egyptian-Israeli relations? Would the Rafah crossing be open? Would he pursue the normalization process started by Mubarak? ${ }^{7}$

Morsi was fully aware of the importance that the Palestinian cause had to Egyptian society and the need to guarantee USA support for his presidency. He also knew that Mubarak's strategic partnership with Israel and the normalization process created too much domestic pressure (Borralho, 2020: 33). Mindful of this, Morsi adopted a pragmatic foreign policy, combining a populist internal discourse with a realistic approach towards Israel, the USA and Hamas. Two important events during the one-year presidency are proof of this.

The first event happened in August 2012, when after asking Israel's permission, Morsi sent the Army to the border with Gaza and ordered the destruction of several tunnels in response to the killing of 16 Egyptian soldiers in North Sinai by a group of militants with

5 Decisions such as the complete closure of the Rafah crossing during Israel's Operation; medical aid to Gaza was forbidden; increasing efforts to dismantle Hamas tunnels; from January to November 2009, the Rafah crossing was open only 33 days out of 301; humanitarian ships could not enter in the Gaza Strip after Israel's Operation was over; and, how the government tried to prevent Egyptian society from protesting in favour of Palestine (PCHR, 2009: 28; Khani, 2013: 109).

6 The MB established the Freedom and Justice Party in 2011 to participate in the first democratic elections in Egypt after the Arab Spring.

7 In a nation-wide speech, Morsi confirmed that he would comply with all international treaties previously signed (which includes the Egyptian-Israel peace treaty) and that Egypt would stand by the Palestinians and their quest for self-determination (Borralho, 2020: 32). 
links to the Gaza Strip (Rigas, 2015: 4). Hamas understood Morsi's decision and stopped all operations throughout the tunnels, arrested several of its members, and let Egyptian authorities question three Hamas leaders linked to this militant group (Rigas, 2015: 4). This first event shows three things: Morsi pragmatic policy made him willing to disregard any religious or ideological links with Hamas if necessary; he adopted a moderate foreign policy towards Israel and even reached new security agreements; Hamas understood Morsi's (fragile) position and tried to help him (Rigas, 2015: 5).

The second event, which bluntly showed how Morsi differed from Mubarak's policies towards the Gaza Strip, was Israel's second major Operation in Gaza, named Operation Pillar of Defense (OPD) ${ }^{8}$, in November 2012. Instead of blaming Hamas for the eruption of the conflict and sidelining them to reach a ceasefire directly with Israel (as done by Mubarak), Morsi recalled his ambassador from Israel and called Khaled Meshaal (Hamas' Leader) to Cairo in order to discuss a ceasefire while doing the same with Israel (Rigas, 2015: 6). These endeavors resulted in the shortest Israeli operation, and fewer victims since the Gaza Strip siege was initiated. Morsi also tried to reconcile Hamas and Fatah because he believed that the Palestinian cause could only succeed if a peace agreement were to be achieved (Borralho, 2020: 34).

However, these are indeed the highlights of a one-year government. If we look at the day-to-day changes instead, it is important to know that Morsi did not fulfil Hamas and Palestinians' expectations in Gaza. In fact, the expectation that the Rafah border would be open continuously for people and commercial purposes never happened. Even more, Morsi reached new security agreements with Israel and kept the economic ones ${ }^{9}$. Indeed, he did not pursue the normalization process and resumed a colder stance; however, the structural changes expected to help the Gaza Strip did not materialize (Borralho, 2020: 35). In sum, Morsi's first and most important goal was to consolidate domestic and international support for his presidency. This failed when Morsi was ousted and sent to jail in a military coup on the $3^{\text {rd }}$ of July 2013.

\section{President Sisi: The Crowning of the Normalization Process}

The new Egyptian President, Abdel Fattah El-Sisi, started by suspending the Constitution and dissolving Parliament. After that, Sisi named the MB as a terrorist organization, a designation he also attached to Hamas (Siddiqui, 2016: 2). This was the beginning of his struggle against political Islam, which both the MB in Egypt and the Hamas in the Gaza Strip embodied. Adding to this, Sisi quickly adopted a foreign policy towards Israel that transcended Mubarak's strategic partnership and reached the rapprochement at the state level (Borralho, 2020: 36).

8 This Operation lasted eight days, and although there was no ground invasion, 167 Palestinians were killed (including 87 civilians and 32 minors). In addition, four Israeli civilians and two security services personnel were killed by Hamas rockets (B'Tselem, 2013: 3).

9 One of the most important economic deals kept by Morsi was the Qualified Industrial Zone agreement (signed by Mubarak's government in December 2004) that allowed Egypt to access the USA market on a duty-free basis as long as the products made in Egypt contained at least 11.7 per cent of Israeli components (Aran and Ginat, 2014: 27). 


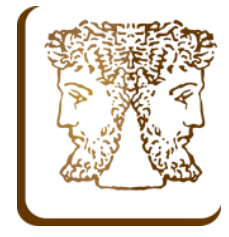

Besides the fight against political Islam, Sisi promoted this rapprochement through common geostrategic concerns and economic deals (Borralho, 2020). Consequently, a centripetal dynamic between Sisi and Netanyahu grew, and several foreign policies were taken by both countries that impacted their relationship and the Gaza Strip. It is also important to consider how instability in the Sinai Peninsula, a buffer zone between Egypt and Israel, has impacted this dynamic. For instance, Sisi sent his Foreign-Minister in a visit to Jerusalem (the first visit in a decade) to discuss Israel's and Egypt's ties in the fight against terrorism and the sharing of intelligence on the Egyptian-Palestinian border (Siddiqui, 2016: 12); Israel re-opened its Embassy in Cairo and Sisi sent a new ambassador to Israel after three years of vacancy; Netanyahu allowed Egypt to deploy more troops in the Sinai Peninsula (Agdemir, 2016: 226).

Nevertheless, what has grounded Sisi's and Netanyahu's centripetal dynamics was Hamas as their common enemy. To start, Sisi made a buffer zone between Sinai and Gaza that Israeli leaders had called for years to hinder Hamas governance. During this process, hundreds of tunnels from Gaza to Sinai were destroyed, worsening the enclave's humanitarian and economic situation. If the public discourse was against Hamas and not Palestinians, the fact is that these decisions especially hurt the Palestinian society. The situation deteriorated again when Israel decided to start the third and biggest military assault in less than six years in the Gaza Strip. Sisi stood beside Israel and against Hamas (Borralho, 2020: 39).

\subsection{Operation Protective Edge}

The events that led to Operation Protective Edge's (OPE) eruption are not settled among scholars. Some scholars blame Hamas for Israel's military operation, and others blame Israel. More than to discuss who escalated to the point where Israel initiated another military operation in Gaza, it is important to strip the western narrative that often sees Hamas as the only one to blame in what goes wrong in this asymmetric fight with Israel. In fact, the decisions taken by Hamas do not happen in a void but instead in a structure where Hamas is one of several actors (Borralho, 2020: 40). Within this structure, we find Israel, Egypt, and the Palestinian Authority. All the processes that happen between them are an outcome of their behave altogether and not only Hamas.

With this in mind, OPE started on the 8th of July 2014 and ended on the 26th of August 2014 after the USA and European Union mediation. Throughout the fifty-one days that this military operation took place, the asymmetry on the numbers demonstrate how Israel premeditated the destruction that they would cause by bombing a besieged enclave from where people cannot escape. For instance, 2,251 Palestinians (including 1,462 civilians) were killed; 551 and 299 of the Palestinians killed were children and women, respectively; 11,231 Palestinians were injured; 1,500 Palestinians were left orphaned; 18,000 house units were destroyed; 108,000 Palestinians became homeless (OCHA, 2015: 2; Filiu, 2014: 58). Six civilians died due to Hamas rockets on the Israeli side, 67 soldiers were killed inside the enclave, and 1,600 Israelis were injured (including 270 children) (OCHA, 2015). What can explain this asymmetry? How has Egypt reacted to this? 
This asymmetry is not only explained but also justified by Israeli officials as correct. To be more precise, Israeli General Eisenkot explained that to groups such as Hamas or Hezbollah, the plan approved was the Dahiya doctrine. This doctrine consists of the use of "disproportionate force" to "(...) cause great damage and destruction" (Khalidi, 2010: $18)^{10}$. When faced with many civilians' deaths, Israel argued that they were "collateral damage". Israeli officials also claim that it was the Palestinians' responsibility to get out of those places because they used preventive warning techniques before the bombings. In other words, Israel shifted the responsibility of killing civilians from its decisions to the victims (Borralho, 2020). With this justification and by framing the Dahiya doctrine within the "war on terror", Israel feels that the killing and destruction are justified, despite being in breach of international law and the Geneva Convention (Borralho, 2020). Does this mean that Hamas launch of rockets towards Israel is justified? Not at all. Hamas is not immune to the possibility of having committed war crimes like Israel. However, it is crucial to establish the asymmetry in the numbers and military capacities between Hamas and Israel. Hamas is at fault, but Israel's instrumentalization of Hamas rockets to justify the atrocities made in Gaza should not be permitted (Borralho, 2020: 42).

Making Gaza's situation worse, this operation was undertaken with total agreement of Sisi that, at the same time, was destroying tunnels and waging military operations in the Sinai Peninsula. In sum, since Sisi came to power, a policy of normalization has been pursued and successfully achieved on the state-level. Moreover, Sisi returned to Mubarak's approach of non-dialogue with Hamas leaders and instead spoke with the PA when he seemed fit. At the societal level, Egyptians were now and for the first time in decades, more distant and less active in their support for Palestine, which can be explained through the authoritarian and repressive military regime that Sisi established ${ }^{11}$. Nevertheless, during the atrocities of OPE, Egyptians came back to the streets in support of Palestine. To conclude, this operation and Sisi's foreign policy towards Gaza and Israel pushed Gaza's dire situation to new levels (Borralho, 2020: 43).

\section{Gaza Strip: Governing under Siege}

Having seen how Egyptian foreign policy evolved since 1981 towards the Gaza Strip and Israel, it is important to look inside the enclave to understand how Hamas and Palestinians have been coping with the siege undertaken by Israel and Egypt. For this reason, it is critical to know that Gaza is, according to the United Nations, the Human Rights Watch and the International Committee of the Red Cross (ICRC), still occupied by Israel despite the 2005 unilateral disengagement plan. Knowing this, it is easier to deconstruct Hamas governance, the de-development of Gaza and evaluate accountability between Israel and Hamas (Borralho, 2020: 45). The main argument of these organizations is that despite no physical presence on the ground, Israel's capacity of exerting its power and impositions into the territory and its inhabitants is what counts

10 Several human rights organizations (such as the Human Rights Watch) classify this strategy as a "serious violation of international law" since it is "indiscriminate, disproportionate, and otherwise unjustified" (Buttu, 2014, apud HRW, 2007: 13; Borralho, 2020: 42).

11 For instance, after Morsi's ouster, the Egyptian army killed more than 600 protesters and injured 4,000 (Siddiqui, 2016: 8). Afterwards, the new military regime also sentenced, in March and April 2014, more than 1,000 Morsi supporters to death (Watanabe, 2014: 4). 
the most (HRW, 2017: 40; ICRC, 2015: 12) ${ }^{12}$. Therefore, adding to the ongoing occupation, to the siege, the military operations, the withdrawal of international aid, the withholding of tax revenues by Israel and the international boycott of their government (Borralho, 2020), what constraints have Hamas faced inside the Gaza Strip that hindered their ability to govern?

After forming a government, Hamas knew that their government legitimacy was linked to their capacity to govern successfully and fulfil their electoral promises ${ }^{13}$ (Borralho, 2020: 49). Therefore, they set themselves out to resolve the most critical issues and started by restoring order and the rule of law. For that, Hamas took a violent approach towards militias and clans whereby, in two years, they were capable of removing them from the streets of Gaza and regained the monopoly over the use of force (Filiu, 2014: 331; Kear, 2019: 166). Regarding the rule of law, Hamas kept the secular system but added the informal system based on the Sharia (Kear, 2019: 159) ${ }^{14}$. By having two systems, which Palestinians could always use, Hamas improved the settlement of disputes and ensured the enclaves' 'Soft-Islamisation' (Brenner, 2017: 196). It is important to highlight that Hamas' conception of law and order was only achieved by reviving Islamic values and prioritizing the social order at the expanse of individual rights. This does not mean that individual rights were not respected by Hamas, however, and as Brenner frames it, "rights and freedoms of the individual (...) were considered to be an effect, rather than a prerequisite, of the 'correct' ordering of society" (2017: 181).

Afterwards, Hamas worked to stop the increasing soft-power that Salafi-Jihadi groups were attaining among several Gaza inhabitants (Kear, 2019: 156). There are different reasons for these groups' soft-power inside the enclave. Namely: Hamas' deradicalization; openness to negotiating and reach ceasefires with Israel; increased pragmatism (which can be seen by the fact that Hamas changed from their initial aim of re-conquering historic Palestine to establishing Palestine in the 1967 territories occupied by Israel) (Borralho, 2020: 49). These decisions were not accepted by some Hamas militants and former Palestinian Islamic groups under Hamas' sphere of influence, especially considering that Hamas had for their whole existence denounced Fatah and the PLO for doing the same, leading to increase disenfranchisement, alienation, and the questioning of Hamas ideological and religious legitimacy (Kear, 2019: 151). In sum, Salafi-Jihadi groups attained a broad support base from Gaza inhabitants due to the perception that Hamas became as complicit as Fatah in continuing the occupation

12 HRW gives the following examples about Israel's capacity to exert its power: "(...) control of movement into and out of the enclave, of Gaza's territorial waters and airspace (not letting Palestinians operate an airport or seaport) (...) controls the Palestinian population registry, the taxes that collects on behalf of the PA and the 'no-go' zones inside Gaza (...)" (HRW, 2017: 37).

13 The most important electoral promises were: restore the rule of law and order; respect public liberties and individual rights; reform the legal system; end corruption; curb down on more radical and militant SalafiJihadist movements; end the militias and clans' disputes; fulfil a 'Soft-Islamization' of Gaza; and the implementation of an Islamic Democracy (Borralho, 2020: 49).

14 The informal system based on the Sharia was a Hamas measure to restore societal security and to alleviate some of the government's administrative burden (after the PA in Ramallah had ordered, in 2006, that their employees in the Gaza Strip boycotted the legal system, leading to its collapse). As a result, Hamas's government created a system with 36 conciliation committees, each supervised by a religious scholar, with the primary function of resolving community disputes (Kear, 2019: 160). As their rulings had no official legal legitimacy, Hamas used the Sharia as an acceptable form of community justice. 
through collaboration with Israel (Kear, 2019: 151). In addition, the socio-economic difficulties also increased these groups' support base.

To counter the Salafi-Jihadi soft-power, Hamas started by taking two approaches towards these groups. The first was mediation, and the second was confrontation ${ }^{15}$. These demonstrated that Hamas was not prepared to see its authority over Gaza questioned. However, in the long run, Hamas also understood that these approaches would not resolve the problem. For this reason, they took a multi-dimensional approach. First, they regained the control and monopoly of Gaza's mosques (and replaced Salafi-Jihadi imams by imams loyal to Hamas to control what was preached to Palestinians) where they controlled the collection and distribution of aid (Kear, 2019: 156). This increased Hamas soft-power. Second, Hamas created a plan of de-radicalization for Salafi-Jihadi members and counter-radicalization for the ordinary Palestinian that showed some support for these groups (Brenner, 2017: 114). In sum, Hamas restored their ideological and religious hegemony, re-established law, order and security, and finally, kept Gaza's humanitarian situation floating.

Of all the electoral promises, the implementation of an Islamic democracy is the most difficult to answer whether they were successful or not. To start, it is important to remember all the internal and external constraints imposed on the Hamas government. Secondly, if Hamas' governance is analysed through Western lens and the concept of liberal democracy, the answer will always be negative. Therefore, it is critical to understand all the processes inside the Gaza Strip and Hamas government decisions from within their specific political and social-economic context that invariably defines their reality (Roy, 2011: 17). With this in mind, and in order to understand if Hamas implemented an Islamic democracy, we should frame Hamas decisions in a continuum where, on one side, we have an Islamic-Theocracy and on the other an IslamicDemocracy (Brenner, 2017: 14). While it is true that Hamas did not establish an IslamicDemocracy per se, as they promised, they should not be accused of being an authoritarian regime. Instead, what guided their decisions was the ever-present goal of consolidation of power and control of the Gaza Strip (Brenner, 2017: 190). To achieve this, the Hamas government changed their decisions contingent on the challenges it faced. For instance, it is fair to say that in areas such as education, the legal system and social morality, the Hamas government embraced a more flexible and moderated posture (Kear, 2019: 274). In addition, the 'Soft-Islamization' was also pursued, as seen before, but without jeopardising Gazans support for their government ${ }^{16}$. Nonetheless, it is also important to acknowledge that concerns "(...) as safeguarding residents' civil and political

15 One example of Hamas' mediation happened when the Jaysh al-Islam group - who openly opposed Hamas - kidnapped three foreigners and students of the Gaza City's University (Brenner, 2017: 84). As a countermeasure, Hamas besieged the clan's entire neighbourhood demonstrating their strength. This led to a ceasefire that assured the release of all the students and foreigners, but that gave, as well, the possibility to Jaysh al-Islam group of retaining some arms for resistance purposes against Israel (Brenner, 2017: 87). When mediation was not successful, confrontation was the second-best option. This happened when the Jund Ansar Allah group declared the creation of an Islamic emirate of Palestine after a sequence of violent attacks inside the Gaza Strip and against Israel. Hamas reacted by killing the group's leaders and several of their militants, besides seizing all of their weapons (Brenner, 2017: 90).

16 For instance, in 2009, Hamas withdrew their decision of implementing gender separation, obligatory hijab for female university students and lawyers in the courts and a ban on women smoking shisha in public spaces after public demonstrations against these decisions (Brenner, 2017: 98). 


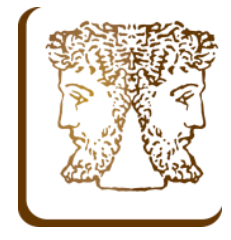

rights (...) were of secondary importance" (Brenner, 2017: 190). Consequently, it is possible to conclude that the shifts in Hamas's behaviour and/or decisions resulted in continuous movement along the Islamic-Theocracy/Islamic-Democracy continuum (Brenner, 2017: 191; Kear, 2019: 273).

\section{Conclusion}

The research reported here is important because it strives to fill the gap when studying the Gaza Strip, its inhabitants and Hamas while being subject to a siege that limits and defines their lives. This is why the relationship and policy of normalization between Gaza's two only neighbours' - Egypt and Israel - is an essential part of the article. Nevertheless, it should be highlighted that I have left out other important topics such as the ongoing conflict between Hamas and Fatah, which also works against the well-being of Palestinians, and the instability in the Sinai Peninsula (that has contributed to the centripetal dynamics between the Egyptian and Israeli governments). Even so, and despite more topics that could have been researched, no other topic created the ongoing humanitarian disaster besides the Israeli and Egyptian siege.

The current situation is so vicious that the United Nations considered the enclave unlivable by 2020 (UN Report, 2017: 3). The siege transformed the Gaza Strip in what Giorgio Agamben describes as the 'camp', meaning, a physical space where "(...) its inhabitants were stripped of every political status and wholly reduced to bare life" (1995: 168). In practical terms, this means that Palestinians from this territory have been stripped of their rights, specifically to a dignified, peaceful and meaningful life. Proofs of this are, for instance, the three major military incursions that Israel made against a besieged territory from which the civilians could not escape and the narrative used to frame and justify so many civilians' deaths by shifting the responsibility to the victims. The number of deaths on both sides also attests to the asymmetric fight between Hamas and Israel. It should make us question how the siege and military incursions happened while the Israeli government is not made responsible for its actions. And, per consequence, also Egypt as it is complicit in what is happening. It is, therefore, essential to call out to the injustices perpetrated against Palestinians while investigating "(...) the juridical procedures and deployments of power by which human beings could be so completely deprived of their rights and prerogatives that no act committed against them could appear any longer as a crime" (Agamben, 1995: 168). Only by doing this can the current narrative of a symmetric fight between Hamas and Israel be refocused to reflect the asymmetry and unequal distribution of power between Israel, Egypt and Hamas.

To conclude, the article should be understood within a debate on the struggle for equality in Palestine and Israel and not further domination and denial. Hence, topics such as the asymmetry between Palestine and Israel, Sinai's Peninsula instability and links to the Gaza Strip, or, even in a broader and theoretical discussion, the deconstruction of the artificial clash of civilizations should be investigated in future academic research. 


\section{References}

Abadi, Jacob (2006). "Egypt's Policy Towards Israel: The Impact of Foreign and Domestic Constraints". Israel Affairs. 12 (1): 159-176.

Abou-El-Fadl, Reem (2012). "The Road to Jerusalem through Tahrir Square: Anti Zionism and Palestine in the 2011 Egyptian Revolution". Journal of Palestine Studies. 41 (2): 626.

Agamben, Giorgio (1995). Homo Sacer - Sovereign Power and Bare Life. Torino: Giulio Einaudi Editore.

Agdemir, A. Murat (2016). "The Arab Spring and Israel's Relations with Egypt: A View from Turkey". Israel Journal of Foreign Affairs. 10 (2): 223-235.

Amnesty International (2009). "Israel/Gaza Operation 'Cast Lead': 22 Days of Death and Destruction". Amnesty International Publications. Accessed at 14 March 2021. Available at: https://www.amnesty.org/en/documents/MDE15/015/2009/en/.

Aran, Amnon and Rami Ginat (2014). "Revisiting Egyptian Foreign Policy towards Israel under Mubarak: From Cold Peace to Strategic Peace". Journal of Strategic Studies. 37 (4): 556-583.

B'Tselem (2009). "Guidelines for Israel's Investigation into Operation Cast Lead". Accessed at 14 March 2021. Available at: https://www.btselem.org/press releases/20090208.

B'Tselem (2013). "Human Rights Violations during Operation Pillar of Defense". Accessed at 14 March 2021. Available at: https://www.btselem.org/press releases/20130509 pillar of defense report.

B'Tselem (2017). "The Gaza Strip". Accessed at 14 March 2021. Available at: https://www.btselem.org/gaza strip.

Borralho, João (2020). Egyptian-Israeli Relations: Past, Present and Future in the Gaza Strip, Published Dissertation, ISCTE University.

Brenner, Björn (2017). Gaza Under Hamas, London: I.B.Tauris \& Co. Ltd.

Buttu, Diana (2014). "Blaming the Victims". Journal of Palestine Studies. 44 (1) :91-96.

Filiu, Jean-Pierre (2014). Gaza. New York: Oxford University Press.

Hroub, Khaled (2002). Political Thought and Practice. Washington: Institute for Palestine Studies.

Human Rights Council (2015). "Report of the detailed findings of the independent commission of inquiry established pursuant to Human Rights Council Resolution S-21/1". Accessed at 14 March 2021. Available at: https://digitallibrary.un.org/record/800872.

Human Rights Watch (2017). "Unwilling or Unable - Israeli Restrictions on Access to and from Gaza for Human Rights Workers". Accessed at 14 March 2021. Available at: https://www.hrw.org/report/2017/04/02/unwilling-or-unable/israeli-restrictions-accessand-gaza-human-rights-workers. 
Human Rights Watch (2007). "Why They Died: Civilian Casualties in Lebanon during the 2006 War". 19 (2007). Accessed at 14 March 2021. Available at: https://www.hrw.org/report/2007/09/05/why-they-died/civilian-casualties-lebanonduring-2006-war.

International Committee of the Red Cross (2015). "International humanitarian law and the challenges of contemporary armed conflicts". Accessed at 14 March 2021. Available at: https://www.icrc.org/en/document/international-humanitarian-law-and-challengescontemporary-armed-conflicts.

Kear, Martin (2019). Hamas and Palestine, Oxon: Routledge.

Khalidi, Muhammad Ali (2010). ""The Most Moral Army in the World": The New "Ethical Code" of the Israeli Military and The War on Gaza". Journal of Palestine Studies. 39 (3): 6-23.

Khani, Arash Beidollah (2013). "Egyptian-Israeli Relations, History, Progress, Challenges and Prospects in the Middle East". Journal of Middle Eastern and Islamic Studies. 7 (3): 93-120.

Meital, Yoram (2010). "Approaching the End of the Mubarak Era: Egypt's Achievements and Challenges". National Security Studies. 1: 175-187.

Palestinian Centre for Human Rights (2009). "23 Days of War, 928 Days of Closure: Life One Year after Israel's Latest Offensive on the Gaza Strip, 27 December 2008 - 18 January 2009". Journal of Palestine Studies. 30 (2010). Accessed at 14 March 2021. Available at: https://www.tandfonline.com/doi/abs/10.1525/jps.2010.XXXIX.3.201.

Rigas, Georgios (2015). Hamas-Egypt Relations during Morsi's Presidency. London: British Association for Islamic Studies.

Roy, Sara (2011). Hamas and Civil Society in Gaza. New Jersey: Princeton University Press.

Siddiqui, Fazzur (2016). "Changing Contours of Egypt's Foreign Policy in the Aftermath of Uprising". Indian Council of World Affairs, 1: 1-18.

Smith, Ron J. (2016). "Isolation Through Humanitarianism: Subaltern Geopolitics of the Siege on Gaza". A Radical Journal of Geography. 48 (3): 750-769.

Stein, Ewan (2011). "The "Camp David Consensus": Ideas, Intellectuals, and the Division of Labor in Egypt's Foreign Policy toward Israel". International Studies Quarterly. 55 (3): 737-758.

Stein, Kenneth W. (1997). "Continuity and change in Egyptian-Israeli relations, 197397". Israel Affairs. 3:3 (4): 296-320.

United Nations Country Team (2017). "Gaza Ten Years Later", Accessed at 14 March 2021. Available at: https://www.un.org/unispal/document/gaza-ten-years-later-uncountry-team-in-the-occupiedpalestinian-territory-report/.

Watanabe, Lisa (2014). "Egypt One Year after Morsi's Ouster". CSS Analysis in Security Policy. 158: 1-4. 